\title{
Titanium Dioxide Exposure Induces Acute Eosinophilic Lung Inflammation in Rabbits
}

\author{
Gil Soon CHOI ${ }^{1 \dagger}$, Chulho OAK ${ }^{1 \dagger}$, Bong-Kwon CHUN ${ }^{2}$, Donald WILSON ${ }^{3}$, Tae Won JANG ${ }^{1}$, \\ Hee-Kyoo KIM ${ }^{1}$, Mannhong JUNG ${ }^{1}$, Engin TUTKUN ${ }^{4}$ and Eun-Kee PARK ${ }^{5 *}$ \\ ${ }^{1}$ Department of Internal Medicine, Kosin University College of Medicine, Republic of Korea \\ ${ }^{2}$ Department of Pathology, Kosin University College of Medicine, Republic of Korea \\ ${ }^{3}$ Department of Occupational Toxicology, Institute of Industrial Ecological Sciences, University of Occupational \\ and Environmental Health, Japan \\ ${ }^{4}$ Ankara Occupational Diseases Hospital, Ministry of Health, Turkey \\ ${ }^{5}$ Department of Medical Humanities and Social Medicine, Kosin University College of Medicine, Republic of \\ Korea
}

Received May 22, 2013 and accepted March 7, 2014

Published online in J-STAGE April 4, 2014

\begin{abstract}
Titanium dioxide $\left(\mathrm{TiO}_{2}\right)$ is increasingly widely used in industrial, commercial and home products. $\mathrm{TiO}_{2}$ aggravates respiratory symptoms by induction of pulmonary inflammation although the mechanisms have not been well investigated. We aimed to investigate lung inflammation in rabbits after intratracheal instillation of $\mathrm{P}_{25} \mathrm{TiO}_{2}$. One $\mathrm{ml} \mathrm{of} 10,50$ and $250 \mu \mathrm{g}$ of $\mathrm{P}_{25} \mathrm{TiO}_{2}$ was instilled into one of the lungs of rabbits, chest computed-tomography was performed, and bronchoalveolar lavage (BAL) fluid was collected before, at 1 and $24 \mathrm{~h}$ after $\mathrm{P} 25 \mathrm{TiO}_{2}$ exposure. Changes in inflammatory cells in the BAL fluids were measured. Lung pathological assay was also carried out at $24 \mathrm{~h}$ after $\mathrm{P}_{25} \mathrm{TiO}_{2}$ exposure. Ground glass opacities were noted in both lungs $1 \mathrm{~h}$ after $\mathrm{P}_{25} \mathrm{TiO}_{2}$ and saline (control) instillation. Although the control lung showed complete resolution at $24 \mathrm{~h}$, the lung exposed to $\mathrm{P25} \mathrm{TiO}_{2}$ showed persistent ground glass opacities at $24 \mathrm{~h}$. The eosinophil counts in BAL fluid were significantly increased after $\mathrm{P25} \mathrm{TiO}_{2}$ exposure. $\mathrm{P25} \mathrm{TiO}_{2}$ induced a dose dependent increase of eosinophils in BAL fluid but no significant differences in neutrophil and lymphocyte cell counts were detected. The present findings suggest that $\mathrm{P}^{25} \mathrm{TiO}_{2}$ induces lung inflammation in rabbits which is associated with eosinophilic inflammation.
\end{abstract}

Key words: Allergy, Eosinophil, Inflammation, $\mathrm{P} 25 \mathrm{TiO}_{2}$ nanoparticle

\section{Introduction}

Over the past decades, advances in nanotechnology have led to their rapid applications in the fields of medi-

\footnotetext{
*To whom correspondence should be addressed. E-mail: ekpark@kosin.ac.kr

${ }^{\dagger}$ These authors contributed equally to this work.

(C) National Institute of Occupational Safety and Health
}

cine, pharmaceutics, biotechnology, energy production and environmental sciences ${ }^{1)}$. The increasing use of nanomaterials in various products at workplaces and in the home setting, including many consumer items such as clothing and plastic wares ${ }^{2)}$ therefore pose an obvious risk to humans.

Titanium dioxide $\left(\mathrm{TiO}_{2}\right)$ nanoparticles (NPs) are one of the most abundantly utilized nanomaterials because of their chemical stability, low toxicity and relatively cheap price $^{3)}$. It is used as a white pigment in paint, food color- 
ing, as an ultraviolet blocker in cosmetics, disinfectant in environment and wastewater, and as a photosensitizer for photodynamic therapy. Oral ingestion and entry through the dermal route are mainly mediated by therapeutic or cosmetic application ${ }^{4,5)}$. The respiratory route is most important because the intake of NPs into the body is from atmospheric air via the upper respiratory tract ${ }^{6}$. $\mathrm{TiO}_{2} \mathrm{NPs}$ are increasingly being manufactured, leading to increased occupational exposure and release into the atmospheric environment. Nano-sized particles are generally more toxic to the lung than their larger-sized counterparts ${ }^{7)}$ which are why there has recently been increasing concern about the impact of $\mathrm{TiO}_{2} \mathrm{NPs}$ in the lung.

Several epidemiological studies have reported that $\mathrm{TiO}_{2}$ NPs exposure at the work place aggravate respiratory symptoms ${ }^{8,9)}$. Besides, earlier studies indicated that inhalation $\mathrm{TiO}_{2}$ NPs can induce pulmonary response such as inflammation, fibrosis, emphysema-like lung injury, and lung cancer ${ }^{6,10,11)}$. However, the pulmonary effects of $\mathrm{TiO}_{2} \mathrm{NPs}$ are not fully understood. Previous animal studies have shown that exposure to $\mathrm{TiO}_{2} \mathrm{NPs}$ causes oxidative stress, induce lung inflammation in the airways and alveolar spaces ${ }^{12,13)}$. Moreover, it has been reported that $\mathrm{TiO}_{2} \mathrm{NPs}$ are able to induce neutrophilic pulmonary inflammation ${ }^{14,15)}$. Recent studies found that $\mathrm{TiO}_{2} \mathrm{NPs}$ cause lung inflammation by activation of T-helper 2 cells and that the exposure of high concentration of $\mathrm{TiO}_{2} \mathrm{NPs}$ in the lung induced an innate immune activation ${ }^{16,17)}$. Although in vitro and in vivo studies suggest that $\mathrm{TiO}_{2}$ NPs cause various forms of pulmonary inflammation ${ }^{11,18)}$, to our knowledge, relatively few studies have investigated the pulmonary effect in a rabbit model, and its pathogenic mechanism. The present study investigated the effect of $\mathrm{TiO}_{2} \mathrm{NPs}$ on rabbit lungs, evaluated by lung image analysis, bronchoalveolar lavage (BAL) fluids examination, and histopathologic analysis.

\section{Materials and Methods}

\section{Titanium dioxide $\left(\mathrm{TiO}_{2}\right)$}

P25 $\mathrm{TiO}_{2}$ nanoparticles (Brunauer-Emmett-Teller (BET) specific surface area of $53.8 \mathrm{~m}^{2} / \mathrm{g}$ ) were obtained from Degussa. The particles were suspended as follows: $1.5 \mathrm{~g}$ of $\mathrm{P} 25 \mathrm{TiO}_{2}$ powder was suspended in $100 \mathrm{ml}$ of distilled water in a pyrex glass beaker, and sonicated for $15 \mathrm{~min}$ by a Branson Digital Cell Disruptor Sonifier 250 (Branson, USA) with a double-stepped microtip ( $3 \mathrm{~mm}$ diameter); this process was repeated 3 times. To stabilize temperature during sonication, the beaker was placed in a bucket of ice throughout the process. The particle suspension was then centrifuged at $3,000 \times \mathrm{g}$ for $20 \mathrm{~min}$ at $20^{\circ} \mathrm{C}$. The supernatant was carefully collected and filtered through a $1 \mu \mathrm{m}$ filter to remove the large agglomerates $(>1 \mu \mathrm{m})$. A given volume of particle suspension was evaporated, after which the weight of the remaining evaporate was measured and $\mathrm{P} 25 \mathrm{TiO}_{2}$ concentration determined $(\mathrm{w} / \mathrm{v}$; in $\mathrm{mg} / \mathrm{ml})$. The hydrodynamic size distribution by number of P25 $\mathrm{TiO}_{2}$ particles suspended in water was analyzed using a Dynamic Light Scattering Zetasizer Nano (Malvern Instruments, UK), and the average particle size was calculated to be $61.9 \pm 5.1 \mathrm{~nm}$.

\section{Animals and study protocol}

Nine Male New Zealand white rabbits (Taesung Laboratory Animal Science, Busan, Republic of Korea) weighing 3.0 to $3.5 \mathrm{~kg}$ were used for this experiment. The rabbits were housed at $20-25{ }^{\circ} \mathrm{C}$ and $50-70 \%$ relative humidity with a $12 \mathrm{~h}$ light/dark cycle. They had free access to water and diet and were acclimatized for at least 1 wk before starting the experiments. Radiologic image analysis (computer-tomography (CT)) was performed to ascertain lung inflammation at 1 and $24 \mathrm{~h}$ after $\mathrm{P} 25 \mathrm{TiO}_{2}$ exposure, and also to investigate the pathogenic mechanism, bronchoalveolar lavage (BAL) was performed at before $\mathrm{P} 25 \mathrm{TiO}_{2}$ exposure, 1 and $24 \mathrm{~h}$ after $\mathrm{P} 25 \mathrm{TiO}_{2}$ exposure. For further histological analysis, all rabbits were euthanized using $\mathrm{CO}_{2}$ gas at $24 \mathrm{~h}$ after $\mathrm{P} 25 \mathrm{TiO}_{2}$ exposure.

Animal experimental procedure was approved by the Animal Research Ethical Committee in Kosin Gospel Hospital, Busan, Republic of Korea.

\section{P25 $\mathrm{TiO}_{2}$ nanoparticles exposure}

Rabbits were anesthetized by intramuscular injection of ketamine $5 \mathrm{mg} / \mathrm{kg}$ (Huons Co., Korea) and xylazine $0.8 \mathrm{mg} /$ $\mathrm{kg}$ (Bayer, Republic of Korea). Oxygen saturation was monitored by pulse oxymeter in the ear. Transbronchial P25 $\mathrm{TiO}_{2}$ instillation was performed using an ultrathin bronchoscope (BF-XP260F, Olympus; Tokyo, Japan). The ultrathin bronchoscope was inserted into the target bronchus as deep as possible under direct vision. The instillation catheter was inserted beyond the visible bronchus through working channel. One $\mathrm{ml}$ of $10 \mu \mathrm{g} \mathrm{P} 25 \mathrm{TiO}_{2}$ was once instilled into the right lung through the catheter and $1 \mathrm{ml}$ of normal saline (as control) was instilled into the left lung $(\mathrm{N}=3)$. One $\mathrm{ml}$ of 50 and $250 \mu \mathrm{g} \mathrm{P} 25 \mathrm{TiO}_{2}$ were instilled in the same way ( $\mathrm{N}=3$ in each group). 


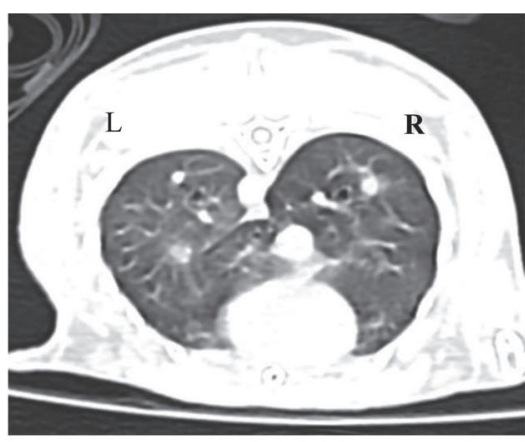

(A)

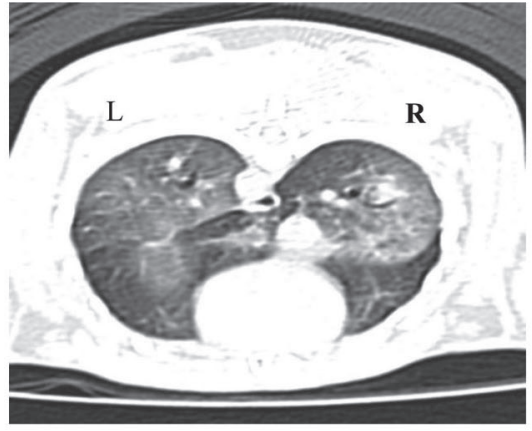

(B)

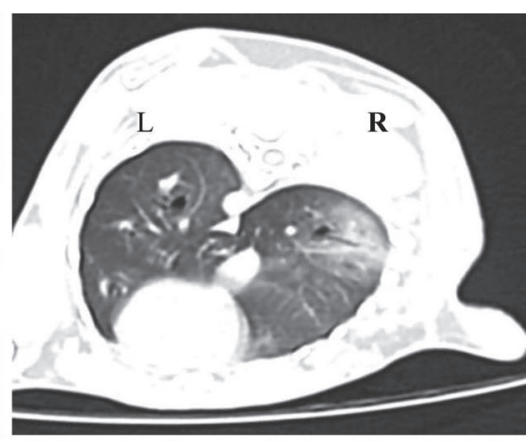

(C)

Fig. 1. Lung inflammatory change by chest CT image analysis. Both lungs were instilled with $10 \mu \mathrm{g} / \mathrm{ml} \mathrm{of} \mathrm{P} 25 \mathrm{TiO}_{2}$ in the right lung and normal saline in the left lung. (A) normal lung at baseline; (B) lung inflammation with ground glass opacity in both lung fields $1 \mathrm{~h}$ after instillation of $\mathrm{P}_{25} \mathrm{TiO}_{2} \mathrm{NP}$; (C) after $24 \mathrm{~h}$ of $\mathrm{P} 25 \mathrm{TiO}_{2} \mathrm{NP}$ exposure, ground glass opacities in the left lung (control) disappeared but they remained in the right lower lung field.

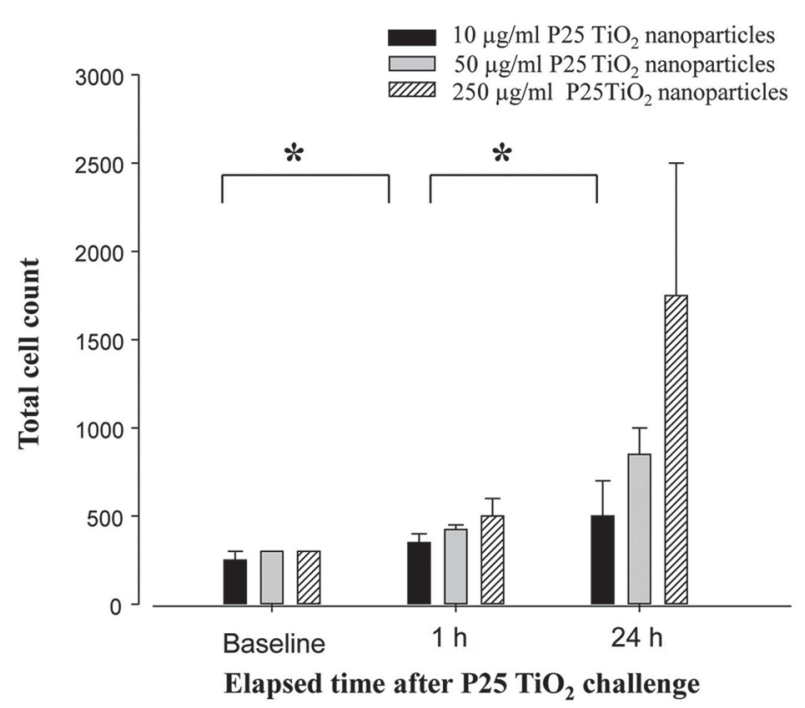

Fig. 2. Total cell count change in bronchoalveolar lavage fluid (BALF). Total cell count in BALF was significantly increased at 1 and $24 \mathrm{~h}$ after $\mathrm{P} 25 \mathrm{TiO}_{2} \mathrm{NP}$ challenge. The bars represent mean \pm $\mathrm{SE} ;$ * $p<0.05$ significantly different from baseline; Mann-Whitney U test.

\section{Bronchoalveolar Lavage and Cell Counting}

Bronchoalveolar lavage (BAL) was performed before P25 $\mathrm{TiO}_{2}$ exposure, at 1 and $24 \mathrm{~h}$ after $\mathrm{P} 25 \mathrm{TiO}_{2}$ exposure through an ultrathin bronchoscope, which was wedged into the 1st branch bronchus of the right lung. Sterile saline solution $(2 \mathrm{ml})$ was instilled through the bronchoscope. The fluid was immediately recovered by gentle suction after each instillation. The measurement of recovered fluids showed an approximately $90 \%$ recovery. To maximize cell viability, the harvested BALF was immediately placed on ice and centrifuged at $1,000 \times \mathrm{g}$ for $10 \mathrm{~min}$. The supernatants were immediately stored at $-80{ }^{\circ} \mathrm{C}$ for further analysis. The cell pellet was used to prepare slides, which were stained according to the May-Grunwald and Giemsa procedures to morphologically assess the cells in the fluid. The differential cell counts were then counted by hemocytometer.

\section{Lung Pathologic Examination Assay}

The lung was harvested for pathologic examination at $24 \mathrm{~h}$ after $\mathrm{P} 25 \mathrm{TiO}_{2}$ exposure. Tissue pretreatments and preparation of hematoxylin and eosin (H\&E) stained slices were carried out as previously described ${ }^{16)}$. They were evaluated by light microscopy.

\section{Statistical Analysis}

Results were expressed as mean \pm standard error (SE). Mann-Whitney U test was used in the case of two independent samples. All analyses were carried out using SPSS 16.0 (SPSS Inc., Chicago, IL, USA). A $p<0.05$ was considered statistically significant.

\section{Results}

\section{Lung image analysis}

To ascertain lung inflammation by $\mathrm{P} 25 \mathrm{TiO}_{2}$ exposure in the rabbit, chest CT was performed after $\mathrm{P} 25 \mathrm{TiO}_{2}$ instillation. Both lungs were clear before the experiment (Fig. 1A), but at $1 \mathrm{~h}$ ground glass opacities (GGO) were noted in each lung instilled with $\mathrm{P} 25 \mathrm{TiO}_{2}(10 \mu \mathrm{g} / \mathrm{ml})$ and normal saline in Fig. 1B. At $24 \mathrm{~h}$ after exposure, persistent lung inflam- 


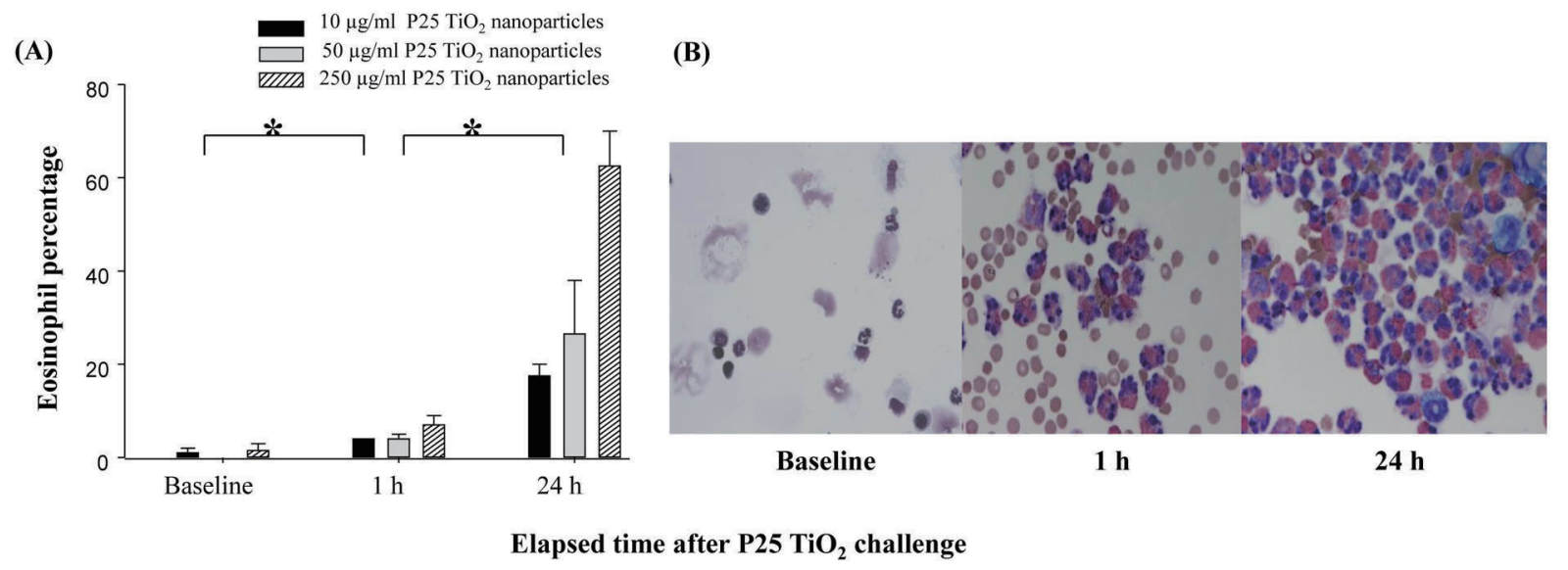

Fig. 3. Eosinophil percentage change in bronchoalveolar lavage fluid (BALF). The increase in eosinophil percentage was noted at 1 and $24 \mathrm{~h}$ after P25 TiO2 NP challenge with dose-dependent responses. (A) the eosinophil count in BALF increased at 1 and $24 \mathrm{~h}$ after P25 TiO2 NP challenges; (B) the photos of eosinophil count in BALF at the dose of $50 \mu \mathrm{g} / \mathrm{ml}$ compared to baseline. The bars represent mean $\pm \mathrm{SE} ; * \boldsymbol{*}<0.05$ significantly different from baseline; Mann-Whitney $\mathrm{U}$ test.

A.

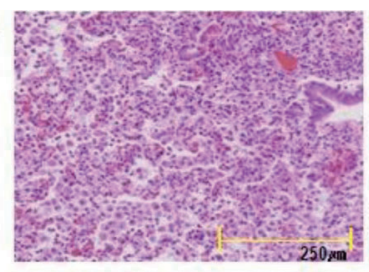

B.

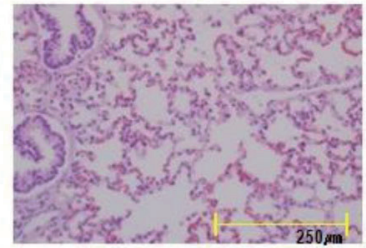

C.

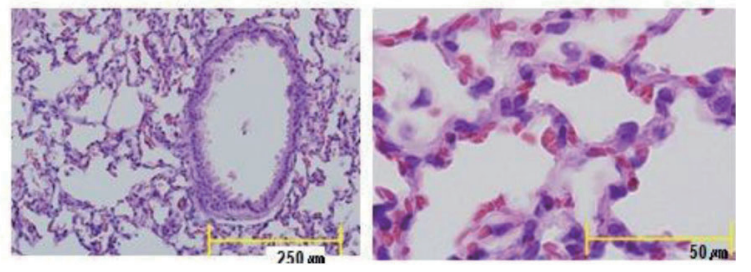

Fig. 4. Pathological examination of the lungs following $\mathrm{P} 25 \mathrm{TiO}_{2}$ $\mathrm{NP}$ challenge. After $24 \mathrm{~h}$ of $\mathrm{P}^{25} \mathrm{TiO}_{2}$ instillation, (A) severe eosinophilic inflammation was noted in the lung that was instilled with $50 \mu \mathrm{g} / \mathrm{ml}$; (B) mild eosinophil inflammation was noted in the lung exposed to the dose of $10 \mu \mathrm{g} / \mathrm{ml}$; (C) normal baseline. Left pane at magnification of $100 \times$ and right pane at a magnification of $1,000 \times$.

mation with GGO was noted in the right lung instilled with $\mathrm{P} 25 \mathrm{TiO}_{2}$, while lung inflammation disappeared in the control lung, instilled with normal saline in Fig. 1C. Similar results were obtained from the experiments using 50 and $250 \mu \mathrm{g} / \mathrm{ml}$ of $\mathrm{P} 25 \mathrm{TiO}_{2}$ (data not shown).

\section{Inflammatory cell changes in BAL fuids}

After one single instillation of $10 \mu \mathrm{g} / \mathrm{ml}$ P25 $\mathrm{TiO}_{2}$ in the rabbit lung, the total cell count in BAL fluids was increased at $1 \mathrm{~h}(p=0.24)$ and $24 \mathrm{~h}(p=0.42)$ (Fig. 2). At 50 and $250 \mu \mathrm{g} / \mathrm{ml}$ of $\mathrm{P}_{2} 5 \mathrm{TiO}_{2}$ the total cell count in BAL fluids was high at $1 \mathrm{~h}$ and $24 \mathrm{~h}$ compared to the baseline.

There was an especially marked increase in eosinophil percentage at $1 \mathrm{~h}(4.0 \pm 0.4 \%)$ and $24 \mathrm{~h}(17.5 \pm 5.5 \%)$ after $10 \mu \mathrm{g} / \mathrm{ml}$ of $\mathrm{P} 25 \mathrm{TiO}_{2}(p<0.05$, Fig. $3 \mathrm{~A})$. When exposed to higher concentrations of $\mathrm{P}_{2} 5 \mathrm{TiO}_{2}(50$ and $250 \mu \mathrm{g} / \mathrm{ml}$ ), a dose-dependent increase in eosinophil percentage was detected at $1 \mathrm{~h}$ and $24 \mathrm{~h}$ (Fig. 3A). The eosinophil count on BAL fluids increased at 1 and $24 \mathrm{~h}$ after $50 \mu \mathrm{g} / \mathrm{ml} \mathrm{P} 25$ $\mathrm{TiO}_{2}$ exposure when compared to baseline (Fig. 3B).

\section{Pathogenic changes after $\mathrm{P} 25 \mathrm{TiO}_{2}$ exposure}

Analysis of BAL fluids confirmed that $\mathrm{P} 25 \mathrm{TiO}_{2}$ induced inflammation in lung tissues. After $24 \mathrm{~h}$ of $\mathrm{P} 25 \mathrm{TiO}_{2}$ instillation $(50 \mu \mathrm{g} / \mathrm{ml})$, severe eosinophilic inflammation was noted in the alveolar, peribronchial and perivascular regions, with moderate hemorrhage (Fig. 4A). Mild eosinophilic inflammation was noted in lung tissues exposed to $10 \mu \mathrm{g} / \mathrm{ml} \mathrm{P} 25 \mathrm{TiO}_{2}$ (Fig. 4B). On the other hand, in the control lung (not exposed to $\mathrm{P} 25 \mathrm{TiO}_{2}$ ), there was no eosinophilic inflammation (Fig. 4C).

\section{Discussion}

Exposure to $\mathrm{TiO}_{2}$ NPs during production or use is most likely to occur via different routes such as skin penetration, ingestion, or inhalation, but, it is believed that the lung is 
the most important target organ ${ }^{19)}$. Although there have been a few studies on the pulmonary effects of $\mathrm{TiO}_{2}$ exposure, to the best of our knowledge, the current study is the first investigation in a rabbit model evaluating acute lung changes after $\mathrm{P} 25 \mathrm{TiO}_{2}$ exposure. Generally, mice or rat models are widely used in research due to ease of handling and their being relatively cost-effective compared to other models. Despite these advantages, mice and humans have considerable differences in lung structure and function which limits their suitability to lung disease studies ${ }^{20,21)}$. The rabbit is known to have a very similarity to human in terms of airway anatomy and responses to inflammatory mediators, although it has not been widely used probably due to limitation of cost and reagent availability. Differences in the pulmonary effects of $\mathrm{TiO}_{2}$ NPs in mouse and rat species have previously been reported ${ }^{22,26)}$. Considering rabbit is phylogenetically closer to human than rodents, our study may further provide important knowledge to understanding the acute lung impacts of $\mathrm{TiO}_{2}$ exposure in human.

$\mathrm{TiO}_{2}$ NPs was previously reported to induce pulmonary response ${ }^{11)}$, which has been mainly evaluated subacute and chronic change by histopathological analysis. There were limitations in that the sequential acute changes following $\mathrm{TiO}_{2}$ exposure were not investigated. This is why image analysis was utilized in our study to evaluate acute lung inflammation following $\mathrm{TiO}_{2} \mathrm{NPs}$ intratracheal instillation. We observed ground glass opacities of acute pneumonitis at $1 \mathrm{~h}$ after single $\mathrm{P} 25 \mathrm{TiO}_{2} \mathrm{NPs}$ exposure. Furthermore we observed persistent pneumonitis in the $\mathrm{P} 25 \mathrm{TiO}_{2}$ exposed lung, as well as newly developed pneumonitis in the P25 $\mathrm{TiO}_{2}$ unexposed opposite lung at $24 \mathrm{~h}$. These results indicate that single instillation of $\mathrm{P} 25 \mathrm{TiO}_{2}$ can induce severe acute pulmonary inflammation. Moreover, previous studies reported that high dose $\mathrm{TiO}_{2}$ NPs cause more severe lung inflammation compared with that of low dose of $\mathrm{TiO}_{2}$, as well as induce persistent pulmonary inflammation ${ }^{23-25)}$. This information may have clinical implications regarding safety in handling of $\mathrm{TiO}_{2} \mathrm{NPs}$.

To understand the pathogenic mechanism of this acute lung inflammation by $\mathrm{P} 25 \mathrm{TiO}_{2}$ exposure, in the present study, BAL fluids and histopathology of lung sections were examined. We found that eosinophils were significantly increased during acute response $(1 \mathrm{~h})$ after $\mathrm{P} 25 \mathrm{TiO}_{2} \mathrm{NPs}$ exposure, which persisted at $24 \mathrm{~h}$ in BAL fluids. Furthermore, eosinophil increases showed a dosedependent pattern. This finding is consistent with those from the study in rat ${ }^{16)}$. Although we did not observe any significant changes of other inflammatory cells, some stud- ies in mouse models have shown increase of neutrophils and macrophages in the lung, as well as epithelial change after challenge with $\mathrm{TiO}_{2}{ }^{10,22,26-28)}$. However, these inflammatory changes were associated with different properties of $\mathrm{TiO}_{2} \mathrm{NPs}$, like crystal structure, surface chemistry, and surface area ${ }^{12,29-31)}$. Therefore, it may be difficult to compare results between NP studies. $\mathrm{TiO}_{2} \mathrm{NP}$ exposure in rats induced innate immune activation of eosinophils in the acute and long-lasting lymphocyte responses ${ }^{12)}$. Recently, it has been reported that lung challenge with $\mathrm{TiO}_{2}$ NP in mice cause inflammation by activation of T-helper 2 cells ${ }^{32)}$. It has also been shown that lung exposure to $\mathrm{TiO}_{2}$ NP aggravates an asthmatic response and also promotes allergic sensitization and lung inflammation in a mouse mode $1^{17,33)}$. In addition, our histopathologic analysis showed severe eosinophil inflammation in the lung after P25 $\mathrm{TiO}_{2}$ challenge, compared with those of the control lung that was not exposed to $\mathrm{P} 25 \mathrm{TiO}_{2}$. Considering that eosinophils are the main effector cells in an allergic inflammation such as asthma ${ }^{34,35)}$, we speculate that P25 $\mathrm{TiO}_{2}$ induce allergic lung inflammation by eosinophil activation. Additional investigations are needed to elucidate how eosinophil activation happens following $\mathrm{TiO}_{2}$ exposure.

In conclusion, this is the first study that investigated lung inflammation after $\mathrm{P} 25 \mathrm{TiO}_{2}$ exposure in a rabbit model and found the particles to induce eosinophilic lung inflammation. Further research is necessary to investigate the mechanism and implications of this eosinophil activation induced by $\mathrm{TiO}_{2} \mathrm{NP}$.

\section{Acknowledgements}

This study was supported by a grant from Kosin University College of Medicine, Busan, Republic of Korea. We thank Professor Toshihiko Myojo (Department of Environmental Health Engineering, Institute of Industrial Ecological Sciences, University of Occupational and Environmental Health, Japan) for his valuable comments.

\section{References}

1) Liu WT (2006) Nanoparticles and their biological and environmental applications. J Biosci Bioeng 102, 1-7. [Medline] [CrossRef]

2) Hoet PH, Brüske-Hohlfeld I, Salata OV (2004) Nanoparticles-known and unknown health risks. J Nanobiotechnology 2, 12. [Medline] [CrossRef]

3) Chen X, Mao SS (2007) Titanium dioxide nanomaterials: 
synthesis, properties, modifications, and applications. Chem Rev 107, 2891-959. [Medline] [CrossRef]

4) Smijs TG, Bouwstra JA (2010) Focus on skin as a possible port of entry for solid nanoparticles and the toxicological impact. J Biomed Nanotechnol 6, 469-84. [Medline] [CrossRef]

5) Yah CS, Simate GS, Iyuke SE (2012) Nanoparticles toxicity and their routes of exposures. Pak J Pharm Sci 25, 477-91. [Medline]

6) Li JJ, Muralikrishnan S, Ng CT, Yung LY, Bay BH (2010) Nanoparticle-induced pulmonary toxicity. Exp Biol Med (Maywood) 235, 1025-33. [Medline] [CrossRef]

7) Bakand S, Hayes A, Dechsakulthorn F (2012) Nanoparticles: a review of particle toxicology following inhalation exposure. Inhal Toxicol 24, 125-35. [Medline] [CrossRef]

8) Garabrant DH, Fine LJ, Oliver C, Bernstein L, Peters JM (1987) Abnormalities of pulmonary function and pleural disease among titanium metal production workers. Scand J Work Environ Health 13, 47-51. [Medline] [CrossRef]

9) Chen JL, Fayerweather WE (1988) Epidemiologic study of workers exposed to titanium dioxide. J Occup Med 30, 937-42. [Medline] [CrossRef]

10) Chen HW, Su SF, Chien CT, Lin WH, Yu SL, Chou CC, Chen JJ, Yang PC (2006) Titanium dioxide nanoparticles induce emphysema-like lung injury in mice. FASEB J 20, 2393-5. [Medline] [CrossRef]

11) Iavicoli I, Leso V, Fontana L, Bergamaschi A (2011) Toxicological effects of titanium dioxide nanoparticles: a review of in vitro mammalian studies. Eur Rev Med Pharmacol Sci 15, 481-508. [Medline]

12) Li B, Ze Y, Sun Q, Zhang T, Sang X, Cui Y, Wang X, Gui S, Tan D, Zhu M, Zhao X, Sheng L, Wang L, Hong F, Tang M (2013) Molecular mechanisms of nanosized titanium dioxide-induced pulmonary injury in mice. PLoS ONE 8, e55563. [Medline] [CrossRef]

13) Gurr JR, Wang AS, Chen CH, Jan KY (2005) Ultrafine titanium dioxide particles in the absence of photoactivation can induce oxidative damage to human bronchial epithelial cells. Toxicology 213, 66-73. [Medline] [CrossRef]

14) Nemmar A, Melghit K, Ali BH (2008) The acute proinflammatory and prothrombotic effects of pulmonary exposure to rutile $\mathrm{TiO} 2$ nanorods in rats. Exp Biol Med (Maywood) 233, 610-9. [Medline] [CrossRef]

15) Warheit DB, Webb TR, Sayes CM, Colvin VL, Reed KL (2006) Pulmonary instillation studies with nanoscale $\mathrm{TiO} 2$ rods and dots in rats: toxicity is not dependent upon particle size and surface area. Toxicol Sci 91, 227-36. [Medline] [CrossRef]

16) Gustafsson $\AA$, Lindstedt E, Elfsmark LS, Bucht A (2011) Lung exposure of titanium dioxide nanoparticles induces innate immune activation and long-lasting lymphocyte response in the Dark Agouti rat. J Immunotoxicol 8, 111-21. [Medline] [CrossRef]

17) Hussain S, Vanoirbeek JA, Luyts K, De Vooght V, Verbeken
E, Thomassen LC, Martens JA, Dinsdale D, Boland S, Marano F, Nemery B, Hoet PH (2011) Lung exposure to nanoparticles modulates an asthmatic response in a mouse model. Eur Respir J 37, 299-309. [Medline] [CrossRef]

18) Chen J, Dong X, Zhao J, Tang G (2009) In vivo acute toxicity of titanium dioxide nanoparticles to mice after intraperitioneal injection. J Appl Toxicol 29, 330-7. [Medline] [CrossRef]

19) Oberdörster G, Oberdörster E, Oberdörster J (2005) Nanotoxicology: an emerging discipline evolving from studies of ultrafine particles. Environ Health Perspect 113, 823-39. [Medline] [CrossRef]

20) Kamaruzaman NA, Kardia E, Kamaldin N, Latahir AZ, Yahaya BH (2013) The rabbit as a model for studying lung disease and stem cell therapy. Biomed Res Int 2013, 691830. [Medline] [CrossRef]

21) Persson CG (2002) Con: mice are not a good model of human airway disease. Am J Respir Crit Care Med 166, 6-7, discussion 8. [Medline] [CrossRef]

22) Bermudez E, Mangum JB, Wong BA, Asgharian B, Hext PM, Warheit DB, Everitt JI (2004) Pulmonary responses of mice, rats, and hamsters to subchronic inhalation of ultrafine titanium dioxide particles. Toxicol Sci 77, 347-57. [Medline] [CrossRef]

23) Zhang Y, Tao J, He P, Tang Y, Wang Y (2009) [Bio-effects of nano-TiO2 on lungs of mice]. Sheng Wu Yi Xue Gong Cheng Xue Za Zhi 26, 803-6 (in Chineses). [Medline]

24) Warheit DB, Yuen IS, Kelly DP, Snajdr S, Hartsky MA (1996) Subchronic inhalation of high concentrations of low toxicity, low solubility particulates produces sustained pulmonary inflammation and cellular proliferation. Toxicol Lett 88, 249-53. [Medline] [CrossRef]

25) Warheit DB, Hansen JF, Yuen IS, Kelly DP, Snajdr SI, Hartsky MA (1997) Inhalation of high concentrations of low toxicity dusts in rats results in impaired pulmonary clearance mechanisms and persistent inflammation. Toxicol Appl Pharmacol 145, 10-22. [Medline] [CrossRef]

26) Rossi EM, Pylkkänen L, Koivisto AJ, Vippola M, Jensen KA, Miettinen M, Sirola K, Nykäsenoja H, Karisola P, Stjernvall T, Vanhala E, Kiilunen M, Pasanen P, Mäkinen M, Hämeri K, Joutsensaari J, Tuomi T, Jokiniemi J, Wolff H, Savolainen K, Matikainen S, Alenius H (2010) Airway exposure to silica-coated $\mathrm{TiO}_{2}$ nanoparticles induces pulmonary neutrophilia in mice. Toxicol Sci 113, 422-33. [Medline] [CrossRef]

27) Ma-Hock L, Burkhardt S, Strauss V, Gamer AO, Wiench $K$, van Ravenzwaay B, Landsiedel R (2009) Development of a short-term inhalation test in the rat using nano-titanium dioxide as a model substance. Inhal Toxicol 21, 102-18. [Medline] [CrossRef]

28) Sager TM, Kommineni C, Castranova V (2008) Pulmonary response to intratracheal instillation of ultrafine versus fine titanium dioxide: role of particle surface area. Part Fibre Toxicol 5, 17. [Medline] [CrossRef]

29) Singh S, Shi T, Duffin R, Albrecht C, van Berlo D, Höhr D, 
Fubini B, Martra G, Fenoglio I, Borm PJ, Schins RP (2007) Endocytosis, oxidative stress and IL-8 expression in human lung epithelial cells upon treatment with fine and ultrafine TiO2: role of the specific surface area and of surface methylation of the particles. Toxicol Appl Pharmacol 222, 141-51. [Medline] [CrossRef]

30) Warheit DB, Brock WJ, Lee KP, Webb TR, Reed KL (2005) Comparative pulmonary toxicity inhalation and instillation studies with different $\mathrm{TiO}_{2}$ particle formulations: impact of surface treatments on particle toxicity. Toxicol Sci 88, 514-24. [Medline] [CrossRef]

31) Kobayashi N, Naya M, Endoh S, Maru J, Yamamoto K, Nakanishi J (2009) Comparative pulmonary toxicity study of nano-TiO(2) particles of different sizes and agglomerations in rats: different short- and long-term postinstillation results. Toxicology 264, 110-8. [Medline]
[CrossRef]

32) Park EJ, Yoon J, Choi K, Yi J, Park K (2009) Induction of chronic inflammation in mice treated with titanium dioxide nanoparticles by intratracheal instillation. Toxicology 260, 37-46. [Medline] [CrossRef]

33) Larsen ST, Roursgaard M, Jensen KA, Nielsen GD (2010) Nano titanium dioxide particles promote allergic sensitization and lung inflammation in mice. Basic Clin Pharmacol Toxicol 106, 114-7. [Medline] [CrossRef]

34) Akuthota P, Xenakis JJ, Weller PF (2011) Eosinophils: offenders or general bystanders in allergic airway disease and pulmonary immunity? J Innate Immun 3, 113-9. [Medline] [CrossRef]

35) Barnes PJ (2011) Pathophysiology of allergic inflammation. Immunol Rev 242, 31-50. [Medline] [CrossRef] 